\title{
PDB BLAST
}

National Cancer Institute

\section{Source}

National Cancer Institute. PDB BLAST. NCI Thesaurus. Code C49050.

A protein profile search method designed to find distant homologs. 